\title{
New findings on energy balance and established wisdom
}

\section{Mario Ciampolini}

Preventive Gastroenterology Unit, Department of Pediatrics, Università di Firenze, Florence, Italy

\section{Email address:}

mlciampolini@fastwebnet.it

\section{To cite this article:}

Mario Ciampolini. New Findings on Energy Balance and Established Wisdom. International Journal of Nutrition and Food Sciences. Vol. 3, No. 4, 2014, pp. 300-306. doi: 10.11648/j.jinfs.20140304.20

\begin{abstract}
Background. Energy balance in blood and body may differ for a day or two although compensating in a month. Most people (60\%) maintain a positive energy balance and a high blood glucose (BG) high energy availability in blood and high resting metabolic rate that correspond to insulin resistance/fattening and ill health. A meal/satiety pattern dictated by the rhythmic arousal of Initial Hunger (IH and IHMP) improved exhaustion of the energy consumed in previous meals and decreased high energy intake, high preprandial BG, high resting metabolic rate (RMR), insulin resistance, overall subclinical inflammation, vascular risks, deteriorations and functional disorders. Methods. We defined Initial Hunger as sensations that spontaneously arise after eating suspension. IH consistently arouse in different groups when BG declined toward $76.6 \pm 3.7 \mathrm{mg} / \mathrm{dL}$. A week diary reported assessments of IH and preprandial BG measurements before the three main meals. Mean BG in a week was stratified within normal BG limits, but different subjects pertained to different strata. Thirty-one untrained control adults maintained his/her own mean and BG stratum for five months. After training, these subjects changed his/her own mean BG to the stratum that was associated with IHMP. Measurements reported by diary, of RMR and of total energy expenditure demonstrated this stratum change. From recruitment, the mean decrease was $15.4 \%$ by indirect calorimetry and $15.5 \%$ by doubly labeled water in a total of 24 toddlers $(\mathrm{P}<0.001)$. Mean $\mathrm{BG}$ thus assessed the deviation of a meal pattern from the mean BG associated with IH (IHMP). Results. In San Diego ASN 2014, we showed the effectiveness of IHMP on regression of fattening/insulin resistance for a long term in 181 adults of mixed body weight who had bowel functional disorders and were clinically normal. However we had earlier designed IHMP for a broader aim as compared to a body loss device. We wanted to educate children and future adults to an intestinal low immune involvement and to the best fitting of intake to body regulations. Thus, we tried to publish the recovery of diarrheic malnourished infants by IHMP in an American Society for Nutrition (ASN) Journal. Subjects were aged less than 15 months, had lower body weight per age than $70 \%$ and recovered through many months and years. This aim was right opposite to weight loss. The ASN Journal rejected the publication as findings of clinical but no nutritional interest. Med Crave promptly published the findings. In a broader thought, the ASN Journal protected the established assistance beliefs and trusts from the confounding intrusion of an innovative, self-help system (IHMP).
\end{abstract}

Keywords: Energy Balance, Meal Energy Load, Malnutrition, Overweight, Immune Improvement

\section{New Findings}

In the nineties, we published a decrease in energy intake in association with elimination of diarrhea relapses in toddlers after meal administration at demand for food $[1,2]$. Subsequent papers confirmed these results and emphasized the long persistence of the taught meal pattern [3,4]. This time-consuming training had the purpose of contrasting fattening/insulin resistance in the educational formation of the future adult. In Western countries, some $60 \%$ of the population fail to adequately limit food intake and two thirds become overweight or obese; $5 \%-10 \%$ develop diabetes [5 - 9]. Few dieticians would disagree that hunger is a signal for starting a meal, but simply suggesting to patients that they should eat when hungry is not likely to bring about improvements in food intake regulation. This is because assertion to be hungry is subjective, and corresponds to different energy availability in blood from an individual to another [6].We were used to observe children in an hospital ward at their meals. Some children cried before food administration, but those who did not cry ate the administered meal as well as those who cried. By receiving no food, the not crying infants went on quietly for hours. Our findings suggested no exhaustion of energy of 
previous meal at each of these customary (conditioned) meals [10 - 12]. Common wisdom suggested that a lower meal intake might automatically and unconsciously compensate the incomplete pre-meal exhaustion. On the other hand, omission of a meal might weaken the infant as well as adults. This objection consists in the mistake that hunger is only an epigastric sensation. Yet Initial Hunger may present as weakness, that is substantiated by a decrease in blood glucose (BG) and in resting metabolic rate. This weakness corresponds to the exhaustion of energy of previous meal, represents a form of Initial Hunger and is a good signal for meal consumption (See next chapter).

We based our medical intervention on physiological relations in the alimentary canal and direct observation of infants. The intention was to better fit meals to the physiological reflexes of intestine and to the phylogeny. Blood glucose (BG) represents a dynamic balance between influx and efflux of energy in blood, and indicates energy availability to body $[13-15]$. The cumulated energy balances determinate BG lowering down to the lowest levels in a day (=before meals). The exhaustion level is objectively comparable among individuals because it arises at an identical, definite moment of energy availability, the lowest in the day. We had the chance to study a group of 89 adults that lost weight when insulin-resistant or overweight and maintained weight when lean and insulin-sensitive [6, 16]. This "homeostatic" group exhausted energy meal by meal, habitually. In this group, we searched the point of complete exhaustion 3 hours after intake of $300 \mathrm{kcal}$. In Figure 1, the lower red line pertains to the mentioned mixed BMI group of 89 subjects. The final value of this group shows exhaustion of previous intake at about 75 $\mathrm{mg} / \mathrm{dL}[16]$. This value is significantly lower than the final BG of groups eating at libitum. The meal pattern associated with regular preprandial exhaustion implies lower energy intake and we found this in all our randomized, controlled studies.

\section{Initial Hunger (IH)}

We ordered to suspend any meal and any thinking to meals, to go on with own job or playing, watching to the arousal of a sensation of hunger for 48 hours, measuring $\mathrm{BG}$ at the arousal and taking note of the characteristics of the hunger sensation as well as of BG value [17]. At subsequent arousals of hunger, the subject could recognize identity of sensation and BG. Many people had a lag time of hours of happy activity although no intake before the first hunger arousal. The distinction between IH and habitual (conditioned) hunger was demonstrated by the simultaneous BG measurement. Two months after training for two weeks, 64 trained and 72 control subjects attended the hospital lab before breakfast after an overnight fasting. All declared current presence or absence of hunger, and estimated BG. A glucose autoanalyzer measured actual BG. Results of this study are reported in Figure 2 [17]. We obtained similar results in a study in children after training in IHMP [18]. A minority of control subjects (Figure 2) had low BG and showed a low error of estimation. We found such minority in all groups at recruitment. The low estimation error demonstrates that these minorities may identify a sensation similar to IH as reference for eating in absence of any training. Given this natural relation to intake in minorities of all studies, and the attainment of similar BG in GGTs of the homeostatic group, as well as the association with insulin sensitivity, IH may represent a physiological signal (natural instinct) that was developed in the phylogeny to guide energy balance to best survival. Initial Hunger $(\mathrm{IH})$ corresponded just to this value in 4 separate studies on mean week BG obtained by homediaries with 21 preprandial BG measurements [6, 17 - 19].
A

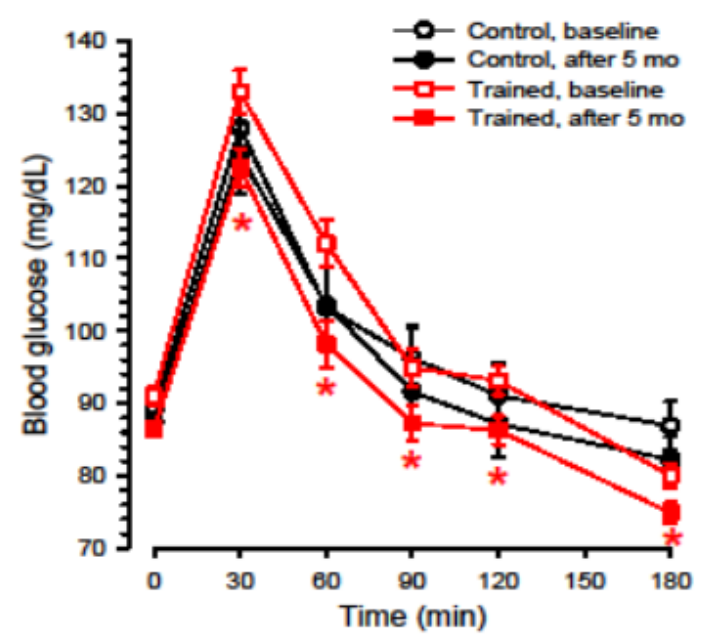

B

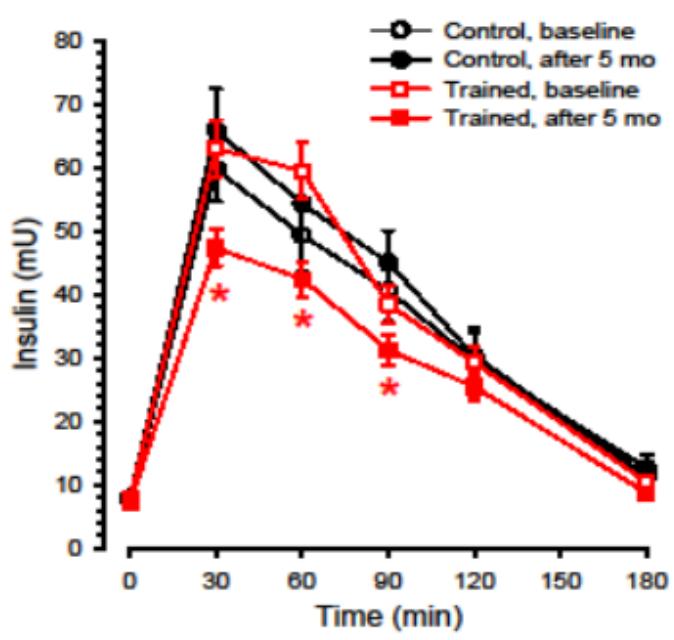

Figure 1. The lower red line pertains to a mixed BMI group of 89 subjects. Overweight and Normal-weight (NW) insulin-resistant subjects lose weight. NW insulin-sensitive subjects maintain stable weight. I.e. The final value indicates exhaustion of previous intake and is about 75 mg/dL. Image courtesy of Ciampolini M, et al. [16]. 
Only ignoring all these demonstrations, experts from NIH (US) dared to assert that there is nothing particularly innovative about this IH proposal. Attention to internal cues to address eating patterns has been a part of standard cognitive behavioral weight loss treatment for quite a long time. To allow intake, common wisdom rely on a state associated with the determination of eating (will to eat). The state may give rise to sensations and physiological reflexes. This arousal is conditioned by cues associated with eating and happens within the habitual stratum for intake (next paragraph). Our innovative work consisted in suggesting eating suspension and Avoidance of conditioning cues to escape from the habitual stratum as an initial, reference step in training.

\subsection{Recognizing Hunger Before Each Meal: Metabolic Consequences}

A total of 181 subjects aged 18-60 years were recruited between the years 1995 and 2000. All subjects entered a randomized controlled study in which the primary outcome was weight [5]. One-hundred and forty-nine subjects completed the full study on body weight and 120 subjects completed a second study whose primary outcome was insulin sensitivity [5, 6]. Sixty-six NW subjects and 38 OW subjects were trained in Hunger Recognition over a 7-week period then followed for a further 3 months.

\subsection{Body Weight}

Hunger Recognition was associated with significant decreases in body weight and body mass index (BMI) in OW subjects compared to controls after 7 weeks of training and after 3 further months of application [5]. BMI decreased from $28.7 \pm 3.5$ to $26.5 \pm 3.5$ in the trained group The decrease was significant in comparison to controls $(P=$ 0.004 ) and in comparison with baseline values of the same group $(P=0.0001)$. Multivariate analysis of variance showed a significant association between training and both BMI and weight. Pre-meal BG emerged as the most significant predictor of variations in BMI and body weight [5]. NW subjects maintained weight overall; however, those trained NW subjects whose BG was high at recruitment also lost weight compared to controls [6].

\section{Stratification of Energy Availability, Insulin Sensitivity (and Metabolic Health)}

A week diary reported food intake, the assessment of $\mathrm{IH}$ and the preprandial BG measurements. Mean BG in a week was stratified within normal BG limits but different subjects pertained to different strata. Each person maintained the own level after five months. Mean BG allowed thus to ascertain the deviation of each meal pattern from the mean BG associated with IH (IHMP). The stratification by mean preprandial BG is positively associated with insulin resistance and vascular risks and is similar (in correlation) to the stratification between glycated hemoglobin and vascular hazard ratios $[6,20]$

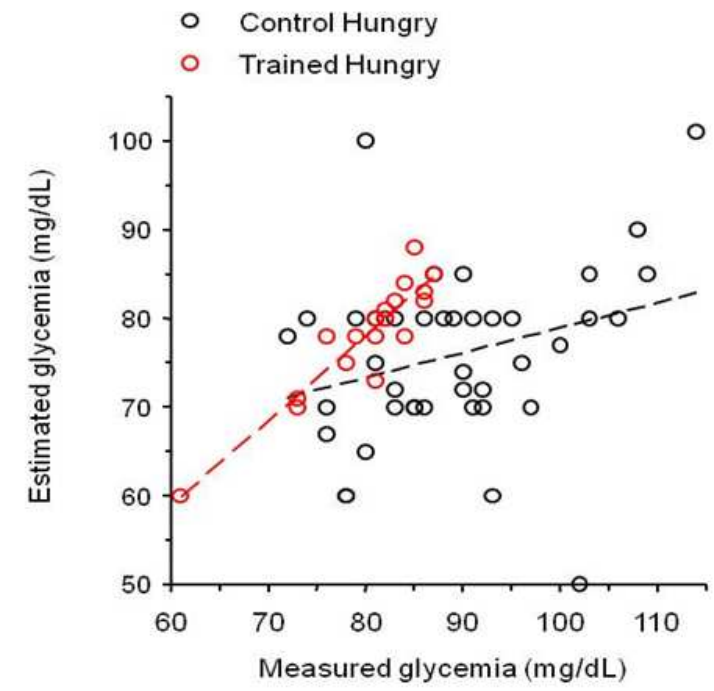

Figure 2. Two months after training for two weeks, 64 trained and 72 control subjects attended the hospital lab before breakfast after an overnight fasting. All declared current presence or absence of hunger, and estimated BG. Actual BG was measured by a glucose autoanalyzer. Image courtesy of Ciampolini M, Bianchi R [17].

The second study included 120 adults, mean age 33 years, of mixed body mass index (BMI) addressed to the Gastroenterology Unit for functional bowel disorders. At recruitment, the 120 subjects showed mean BG at one personal level of ten possibilities [6]. Thirty-four subjects were below $81.8 \mathrm{mg} / \mathrm{dL}$ (LBG) and 55 were over (HBG). Thirty-one control subjects did not change their mean BG after 5 months. The 34 LBG trained subjects only decreased weekly-diary BG standard deviation in comparison with controls. The 55 HBG subjects showed higher mean insulin resistance, HbA1c, other cardiovascular risk factors, and higher bodyweight compared with the 34 LBG subjects. A total of 41 out of the 55 HBG subjects regressed to LBG with training. After training, only HBG subjects, compared with HBG controls, significantly decreased preprandial BG from $91.6 \pm 7.7$ $\mathrm{mg} / \mathrm{dL}$ to $81.0 \pm 7.7 \mathrm{mg} / \mathrm{dL}$, in association with a decrease of $\mathrm{HbA} 1 \mathrm{c}$ from $4.81 \% \pm 0.44 \%$ to $4.56 \% \pm 0.47 \%$, of GTT insulin AUC from $244 \pm 138 \mathrm{mU} / \mathrm{L}$ to $164 \pm 92 \mathrm{mU} / \mathrm{L}$, and of energy intake from $1872 \pm 655 \mathrm{kcal}$ to $1251 \pm 470 \mathrm{kcal}$ $(P<0.001)$, with an increase of indices of insulin sensitivity from $5.9 \pm 3.3$ to $9.8 \pm 5.6$ and of beta cell function from $1.0 \pm 0.7$ to $1.4 \pm 1.1(P<0.05)$. The wellbeing, nutrition, and cardiovascular trials showed no significant differences between trained and control subjects in the LBG group. In the trained HBG group, the decreases in days with abdominal pain or stomach ache, in diastolic blood pressure and in LDL to HDL cholesterol ratio, and 
the increase in the HDL cholesterol were significant and significantly larger than in the control HBG group $(P<$ $0.005)[6]$.

\section{Findings in Undernourished Infants}

The healthy small intestinal mucosa contains half immune cells in human body [21 - 43]. The immune cell number is heavily influenced by bacteria in experimental studies in germ-free animals, and immune activation promotes diarrhea [21 - 43]. We counted bacteria on intestinal mucosa of 126 children, and found a significant decrease with passage of time since the previous meal. The difference was 39 times on atrophic, celiac mucosa and 11 times on normal mucosa [39]. Five $\%$ to fifteen $\%$ of intestinal bacteria are immunogenic [34]. During digestion, a low bacterial growth might be a sound, hygienic principle. We postponed food administration until arousal of the first hunger manifestation but no longer than this, and thus prevented relapses [1 - 5]. After adoption of IHMP, energy intake decreased about $20 \%$, total daily expenditure by $15.5 \%$, resting metabolic rate by $15.4 \%$ [19]. IHMP could reduce high energy intake, incomplete exhaustion of the energy consumed in previous meals, high preprandial BG, high RMR, insulin resistance, and a list of associations: immune involvement in intestinal mucosa, overall subclinical inflammation, vascular risks, deteriorations and functional disorders.

During the forty years of activity of the pediatric Gastroenterology Unit of Florence University, we randomly assigned each subject to control and intervention groups. The largest groups consisted in diarrheic children. The aim of this large, prospective study was a prevention from fattening/insulin resistance and diabetes. We investigated also 6 trained mother/child pairs in comparison with 3 control pairs (Figures 3 and 4) [44]. We conceived IHMP to improve intestinal absorption by decrease of immune involvement in intestinal mucosa as well as throughout the body (overall subclinical inflammation). The nine malnourished infants had a weight per age lower than $70 \%$ and chronic diarrhea in the first 15 months of age. Organic diseases were excluded by conventional procedures, including intestinal biopsy. Compliance, intake, and anthropometry were recorded in hospital for 2 months, and then by frequent visiting and 7-day home diary under intervention for 5 total times in two years. Energy intake decreased from $126 \pm 21 \mathrm{kcal} / \mathrm{kg} / \mathrm{d}$ to $85 \pm 6 \mathrm{kcal} / \mathrm{kg} / \mathrm{d}$ in treated infants and from $111 \pm 53 \mathrm{kcal} / \mathrm{kg} / \mathrm{d}$ to $107 \pm 37$ $\mathrm{kcal} / \mathrm{kg} / \mathrm{d}$ in the first 2 months of study $(\mathrm{P}<0.01$ on longitudinal differences). Days with vomiting became null after 2 months of treatment, whereas 4 or 5 events every 60 days persisted in control subjects for all follow-ups. Further longitudinal differences were significant on days with diarrhea after three months, and on plasma triglycerides at the two sampled times during treatment. These assessments were all significant by chi square for trend during the follow up $(\mathrm{P}<0.01)$. Serum triglycerides decreased from
$148 \pm 27 \mathrm{mg} / \mathrm{dL}$ to $70 \pm 10 \mathrm{mg} / \mathrm{dL}$ under intervention, and increased from $119 \pm 47 \mathrm{mg} / \mathrm{dl}$ to $139 \pm 59 \mathrm{mg} / \mathrm{dl}$ in controls ( $\mathrm{P}<0.002$ on the difference). Values after two years of follow-ups were respectively: $73.2 \pm 12.3 \mathrm{mg} / \mathrm{dL}$ and $89 \pm 37 \mathrm{mg} / \mathrm{dL}(\mathrm{P}<0.05)$. Toward the end of the study, anthropometric measurements in treated infants increased per age from recruitment with differences from control subjects that were not significant in the longitudinal comparisons between groups. Weight per age reached 88.8 $\pm 8.7 \%$ under intervention, and $79.7 \pm 10.2 \%$ in controls after two years. These differences were not significant at single times but were significant by chi square for trend ( $\mathrm{P}$ $<0.01)$. Psycho- motor development was normal except for one control infant.

We conclude that high triglycerides and insulin resistance are involved in the development of persistent diarrhea, overall subclinical inflammation and malnutrition in these undernourished infants as in the development of functional bowel disorders and overweight in adults [6]. IHMP was effective for the long maintenance in malnourished infants [44], in diarrheic infants [3, 4], and in overweight people [5]. We studied 43 trained and 43 control children from the second to the eleventh year of age. The children were diarrheic in the second year but soon recovered from diarrhea. At the mean age of 10.1 years, the increase in $\%$ weight for height was $3.1 \% \pm 12.5 \%$ and $10.3 \% \pm 13.7 \%$ in trained and control subjects. The longitudinal difference was significant at $\mathrm{P}<0.05$.

Considering together effects of IHMP on malnourished infants, on chronic diarrhea, on vascular risks and fattening/diabetes, considering the spontaneous maintenance by a minority of population and considering the long term maintenance of the skill and intention to limit intake, considering the association of IHMP with low intake and low total energy expenditure as well as low RMR, high insulin sensitivity, low vascular risks, we conclude that IHMP is a safer way of eating than ad libitum intake.

\section{Common Wisdom}

At the 2014 ASN (EB) San Diego meeting we presented: "Learning sensations of pre-meal hunger: effects on energy intake, body weight and insulin sensitivity". A written version (MS ID\#: ADVANNUT/2014/006346) will be available. The use of IHMP seemed as a device for weight loss but this was misleading. Thus I submitted to the Journal of Nutrition (ASN) the above research investigation: "Initial Hunger" for all? A study on undernourished infants" [44]. The intention of the submission to J Nutrition was to correct the view on IHMP as an only body weight loss device. ASN ( $\mathrm{J}$ Nutrition) refused this meaning, and considered the manuscript as a clinical study on malnutrition to be addressed to a clinical Journal. This limitation is in contrast with the intention of the expert (researcher, i.e. myself) to widen the application of IHMP. This type of divergence (between the established authority 
and the expert) has been well debated since Plato and Aristotle. Feyerabend recently emphasized the distress caused by Galileo's findings in the Authorities and population of his age [45]. The distress did not simply consist in a power diminution for the established Authorities. A well consolidated outlook was overthrown and the population entered a uncertain state about actual events, facts and about trust attribution, a disordered state. Current societies rely and trust on the activities of a big number of experts in thousands of different matters. The single person is an expert in his/her own job but has to rely and trust on someone who is competent in other matters. Institutional authorities preserve this network of established trusts to maintain efficient activity, production and order for all. The institutional Authority may try to stop novelty intrusion. I operated in a University hospital but the director did not refrain from protecting young physicians from the observed achievements: we all think the same, only you have a different thinking. Oh well, like in Breshnev's Russia!. I repeated. The scientist/researcher faces the Promethean myth, and may be happy with the open mind of ASN, at least in comparison with old Italy and worse, with Breshnev's Russia. Novelty diffusion was worse before Internet. Referees evaluated the submitted manuscripts by consolidated wisdom. Few fields were open to innovation: genomics, virology, epidemiology, drugs. The association between insulin resistance and overall inflammation was proposed in 1923 and 1963 [46, 47], but was accepted in 1988 [27]. The explosion of internet Journals overthrew the relations with authors, and Journals seem now to beg authors to submit manuscripts. Does still exist a Scientific Journal hierarchy? Yes, it consists in the impact factor. Is it useful for knowledge diffusion? Currently exists internet, the limitation to innovation is bland, although being noxious because may sustain easy, well consolidated ill beliefs and associated patterns. Presumably, a new hierarchy will develop, and limitation will grow and impair again knowledge progression. It is human!

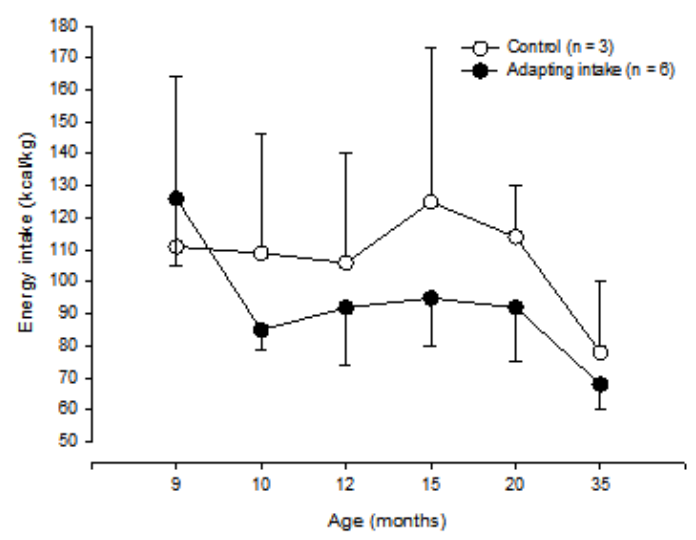

Figure 3. Daily energy intake in treated (6, black circles) and control (3, white circles) subjects during two follow up years. $P<0.05$ in the longitudinal comparison between decreases from the assessment at recruitment and subsequent assessment. Image courtesy of Ciampolini $M$, et al. [44]

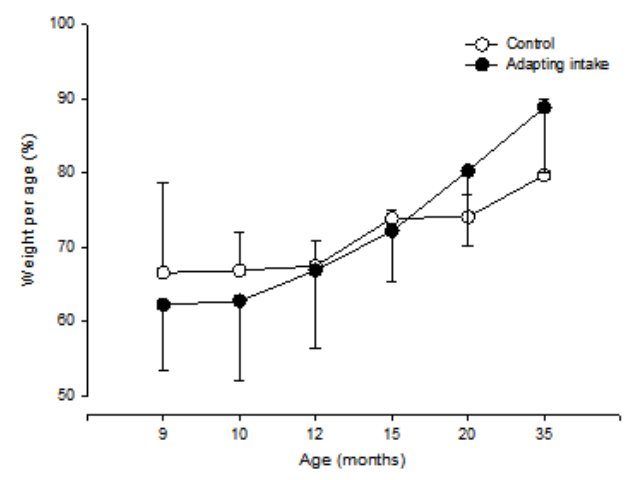

Figure 4. Symbols like in Figure 1. Image courtesy of Ciampolini M, et al. [44].

\section{References}

[1] Ciampolini M, Vicarelli D, Seminara S. Normal energy intake range in children with chronic non-specific diarrhea. Association of relapses with the higher level. J Pediatr Gastroenter Nutr 1990; 11: 342-50.

[2] Ciampolini M, Vicarelli D, Bini S. Choices at weaning, main factor of ingestive behavior. Nutrition 1991; 7: 51-54.

[3] Ciampolini M, Bini S, Giommi A, Vicarelli D, Giannellini V. Same growth and different energy intake in chronic nonspecific diarrhea children in a four-year period. Intern $\mathrm{J}$ Obesity 1994; 18: 17-23.

[4] Ciampolini M, Borselli L, Giannellini V . Attention to metabolic hunger and its effects on Helicobacter pylori infection. Physiol Behav 2000; 70: 287-296.

[5] Ciampolini M, Lovell-Smith D, Sifone M: Sustained selfregulation of energy intake. Loss of weight in overweight subjects. Maintenance of weight in normal-weight subjects. Nutr Metab (Lond). 2010;7:1-4. $<$ http://www.nutritionandmetabolism.com/content/7/1/4

[6] Ciampolini M, Sifone M. Differences in maintenance of mean Blood glucose (BG) and their association with response to "Recognizing Hunger". I J Gen Med 2011, 4, 403-412.

$<$ http://www.dovepress.com/articles.php?article id=7556\&l $=$ BLE3wJ5qmAFXtoDHARiR88kX112820>

[7] Hossain P, Kawar B, El Nahas M. Obesity and diabetes in the developing world - a growing challenge. N Engl J Med. 2007;356(3):213-215.

[8] Mozaffarian D, Hao T, Rimm EB, Willett WC, Hu FB. Changes in diet and lifestyle and long-term weight gain in women and men. N Engl J Med. 2011;364(25):2392-2404.

[9] Sumithran P, Prendergast LA, Delbridge E, et al. Long-term persistence of hormonal adaptations to weight loss. N Engl J Med. 2011; 365(17):1597-1604.

[10] Ciampolini M. Initial hunger and exhaustion of previous energy intake- Recognizing hunger, and energy balance (Rev Recent. Res. Devel. Nutrition, 8 (2011): ISBN: 97881-308-0468-2

$<$ http://www.ressign.com/UserBookDetail.aspx?bkid $=1281$ \&catid $=247>$ 
[11] Ciampolini M. Eliciting Clear-Cut Initial-Hunger at Proper Time. OMICS Publishing Group 2012: $<$ http://dx.doi.org/10.4172/2161-1017.1000102>

[12] Ciampolini M, Editor. Meal by meal dynamic balance of energy in blood. Research Signpost, 37/661(2), Vazhappalli Jn., Fort Post Office, Trivandrum-695 023, Kerala, INDIA. ISBN: $<$ http://www.trnres.com/ebook.php>

[13] Gavin JR: Pathophysiologic mechanisms of postprandial hyperglycemia. Am J Cardiol 2001, 88:S4-S8

[14] de Graaf C, Blom WAM, Smeets PAM, Stafleu A, Hendriks HFJ:Biomarkers of satiation and satiety. Am J Clin Nutr 2004,79:946-961.

[15] 10 Elliott SS, Keim NL, Stern JS, Teff K, Havel PJ: Fructose, weight gain, and the insulin resistance syndrome. Am J Clin Nutr 2002,76:911-922.

[16] Ciampolini M, Lovell-Smith D, Bianchi R, de Pont B, Sifone $\mathrm{M}$, van Weeren $\mathrm{M}$, de Hahn W, Borselli L, Pietrobelli A. Sustained self-regulation of energy intake. Initial hunger improves insulin sensitivity. J Nutr Metab 2010, Article ID 286952, 7 pages. doi:10.1155/2010/286952 $<$ http://www.hindawi.com/journals/jnume/aip.286952.html >

[17] Ciampolini M, Bianchi R: Training to estimate blood glucose and to form associations with initial hunger. Nutr Metab (Lond). 2006; 3:42.

$<$ http://www.nutritionandmetabolism.com/content/3/1/42>

[18] Ciampolini M. Requested meals versus scheduled meals. I J Gen Med 2012:5 1-9. DOI: doi.org/10.2147/IJGM.S29889 $<$ http://www.dovepress.com/article 9690.t9911652>

[19] Ciampolini M, Brenna JT, Giannellini V, Bini S. Interruption of scheduled, automatic feeding and reduction of excess energy intake in toddlers. Intern J Gen Med 2013, $<\mathrm{http} / / /$ www.dovepress.com/article_12104.t15115810 $><\mathrm{htt}$ p://www.ncbi.nlm.nih.gov/pubmed/23393411>

[20] Selvin E, Steffes MW, Zhu H, Matsushita K, Wagenknecht L, Pankow J, Coresh J, Brancati FL. Cardiovascular Risk in Nondiabetic Adults. N Engl J Med 2010;362:800-11.

[21] Brandtzaeg P, Halstensen T S, Kett K, Krajci P, Kvale D, Rognum TO, Scott H, Sollid LM. Immunobiology and immunopathology of human gut mucosa: humoral immunity and intreaepithelial lymphocytes. Gastroenterology 1989; 97:1562-1584.

[22] Abrams GD. Microbial effects on mucosal structure and function. Am J Clin Nutr 1977;30:1880-1886.

[23] Kinugasa T, Sakaguchi T, Gu X, Reinecker HC. Claudins regulate the intestinal barrier in response to immune mediators. Gastroenterology 2000; 118: 1001-1011.

[24] Perez PF, Doré J, Leclerc M, Levenez F, Benyacoub J, Serrant P, Segura-Roggero I, Schiffrin EJ, Donnet-Hughes A. Bacterial Imprinting of the Neonatal Immune System: Lessons From Maternal Cells? Pediatrics 2007; 119: e724e732.

[25] Smith CW. Diet and leukocytes. Am J Clin Nutr 2007; 86: 1257-1258.

[26] Reaven GM: The metabolic syndrome: is this diagnosis necessary? Am J Clin Nutr 2006; 83:1237-1247.
[27] Reaven, G.M. Role of insulin resistance in human disease. Banting Lecture 1988. Diabetes 1988;37: 1595-1607;.

[28] Wilson KT, Crabtree JE. Immunology of Helicobacter pylori: Insights Into the Failure of the Immune Response and Perspectives on Vaccine Studies. Gastroenterology 2005; $129: 380-383$

[29] Hecht G. In the Beginning Was Helicobacter pylori: Roles for Microbes in Other Intestinal Disorders. Gastroenterology 2007; 132: 481-483.

[30] Abraham C, Cho JH. Inflammatory bowel disease. N Engl J Med 2009; 361:2066-2078.

[31] Sartor B: Microbial influences in Inflammatory Bowel Disease. Gastroenterology 2008; 134:577-594.

[32] Davidson GP, Robb TA, Kirubakaran CP. Bacterial contamination of the small intestine as an important cause of chronic diarrhea and abdominal pain: diagnosis by breath hydrogen test. Pediatrics 1984;74:229-235.

[33] Azpiroz F, Bouin M, Camilleri M, et al. Mechanisms of hypersensitivity in IBS and functional disorders. Neurogastroenterol Motil. Jan 2007;19(1 Suppl):62-88.

[34] van der Waaij LA, Limburg PC, Mesander G, van der Waaij, D. In vivo IgA coating of anaerobic bacteria in human faeces. Gut 1996;38:348-354

[35] Dinan TG, Quigley EM, Ahmed SM, Scully P, O'Brien S, O'Mahony L., O'Mahony S, Shanahan F, Keeling N. Hypothalamic-pituitary-gut axis dysregulation in irritable bowel syndrome: plasma cytokines as a potential biomarker? Gastroenterology 2006;130:304-311.

[36] Ohman L, Simrén M. Pathogenesis of IBS: role of inflammation, immunity and neuroimmune interactions. Nat Rev Gastroenterol Hepatol 2010; 7(3):163-173.

[37] Spiller R, Garsed K. Postinfectious irritable bowel syndrome. Gastroenterology 2009;136(6):1979-1988.

[38] Li X, Chen H, Lu H, Li W, Chen X, Peng Y, Ge Z. The study on the role of inflammatory cells and mediators in post-infectious functional dyspepsia. Scand. J Gastroenterol 2010;45(5):573-581. Sartor B. Microbial influences in Inflammatory Bowel Disease. Gastroenterology 2008; 134:577-594.

[39] Ciampolini M, Bini S. Orsi A. Microflora persistence on duodeno-jejunal flat or normal mucosa in time after a meal in children. Physiol Behav 1996; 60: 1551-1556.

[40] Brunser O, Eidelman S, Klipstein FA. Intestinal morphology of rural Haitians. A comparison between overt tropical sprue and asymptomatic subjects. Gastroenterology $1970 ; 58: 655-668$.

[41] Gorbach SL, Banwell JG, Chatterjee BD, Jacobs B, Sack RB. Acute, undifferentiated human diarrhea in the tropics. I Alterations in intestinal microflora. J Clin Invest 1971; $50: 881-889$

[42] Terziæ, J, Grivennikov, S, Karin, E, Karin, M. Inflammation and Colon Cancer. Gastroenterology 2010:138:2101-2114.

[43] Liebregts T, Adam B, Bredack C, Röth A, Heinzel S, Lester S, Downie-Doyle S, Smith E, Drew P, Talley NJ, Holtman G. Immune Activation in Patients With Irritable Bowel Syndrome. Gastroenterology 2006; 132: 913-920. 
[44] Ciampolini M, Bianchi R, Sifone M., Riccardo Bianchi and Massimiliano Sifone "Initial Hunger" for All? A Study on Undernourished Infants. Journal of Pediatrics \& Neonatal Care. Volume 1 Issue 2 - 2014.

[45] Feyerabend P. Philosophy, chapter 9, Biddles Ltd, Guilford, GB, 1987.
[46] Kylin E. Studien ueber Hypertonie-HyperglykamieHyperurikamie syndrome. 1923, Zentralblatt fur innere Medizin, 44.

[47] Randle PJ, Garland PB, Hales CN, Newsholme EA. The glucose-fatty acid cycle: its role in insulin sensityvity and the metabolic disturbances of diabetes mellitus. Lancet 1963;93:785-789. 